\title{
Quality of life assessment for patients with elbow arterio-venous fistula - a multicenter study
}

\author{
Stelian PANTEA ${ }^{1}$, Iustinian BENGULESCU ${ }^{2}$, Dragoș GAROFIL ${ }^{3}$, \\ Corina PANTEA ${ }^{4}$, Victor STRÂMBU 5
}

\begin{abstract}
End stage renal disease (ESRD) is a chronic medical condition that has become a public health problem. A vascular access is mandatory for patients with ESRD in order to receive hemodialysis. The elbow fistula is the most used procedure for creating the vascular access. Maintaining the fistula's patency represents a constant struggle for these patients representing their lifeline. Our goal was to evaluate the impact that the elbow fistula has on the patient's life quality (QoL). We performed a multicenter study in the $2^{\text {nd }}$ surgical clinic, Timisoara Emergency County Hospital and the General Surgery department, "Carol Davila" Nephrology Clinical Hospital, Bucharest. We included only the patients that had their first vascular access procedure (elbow fistula) created in one of our centers. All patients completed the SF-36 questionnaire before surgery and at 6 months and 1 year after surgery. The SF-36 score has two major categories: the physical component summary (PCS) and the mental component summary (MCS). The results showed a decrease in the patients QoL after surgery (13.63\% for the PCS and $6.87 \%$ for the MCS). Also elderly patients (>60 years age) had a decrease in the QoL of $19.11 \% \mathrm{PCS}$ and $8.17 \% \mathrm{MCS}$ compared to $10.20 \%$ PCS and 4.12\%MCS for younger patients. Socio-economic status also has an impact on the patients QoL. Once the vascular access is created, patients must maintain their new lifeline through thorough self care actions and also by restricting their activities affecting the patient's QoL. Further studies are required to help clarify the association between vascular access and the patient's QoL.
\end{abstract}

Keywords: Quality of life, hemodialysis, vascular access, arterio-venous fistula

\section{Rezumat}

Boala renală în stadiu final reprezintă o afecțiune cronică care a devenit o problemă de sănătate publică.Abordul vascular funcțional este obligatoriu pentru ca pacienții cu boală renală în stadiu final să poată intra în regim de hemodializă. Fistula arterio-venoasă la plica cotului reprezintă cea mai folosită varianta de abord vascular. Pentru acești pacienți o fistulă arteriovenoasă funcțională reprezintă linia de salvare, iar menținerea patentei acesteia reprezintă o continuă luptă pentru pacienți. Scopul acestei lucrări este de a evalua impactul fistulei arterio-venoase de la nivelul plicii cotului asupra calității vieții (QoL). Pentru aceasta am realizat un studiu multicentric care s-a desfășurat în cadrul Clinicii II Chirurgie a Spitalului Clinic Judetean de Urgență Timișoara precum și în cadrul Clinicii de Chirurgie Generală a Spitalului Clinic de Nefrologie Dr. Carol Davila din București. Au fost incluși în studiu doar pacienții cărora li s-a practicat ca primă procedură de abord vascular o fistulă arterio-venoasă la nivelul plicii cotului. Toți pacienții au completat chestionarul SF-36 înainte de intervenția chirurgicală și la 6 și 12 luni după operație. Scorul chestionarului SF-36 se poate împarți în două componente majore care evaluează starea sănătății fizice (PCS) și starea sănătății mentale (MCS). Rezultatele au dovedit o scădere a QoL după operație (13,63\% pentru PCS și 6,87\% pentru MCS).De asemenea, vârstnicii (peste 60 ani) au prezentat o scădere a QoL de 19,11\% pentru PCS și 8,17\% pentru MCS comparativ cu 10,20\% pentru PCS și 4,12\% pentru MCS în cazul pacienților mai tineri. De asemenea, și statusul socio-economic are un impact asupra calități vieții acestor pacienți. După realizarea abordului vascular, pacienții trebuie să contribuie la menținerea functionabilității acestuia prin măsuri restrictive asupra calității vieții și asupra activităților zilnice. Studii următoare asupra acestui domeniu sunt necesare pentru a clarifica mai în detaliu legătura dintre prezența abordului vascular și impactul acestuia asupra calității vieții acestor pacienți.

Cuvinte cheie: calitatea vieții, hemodializă, abord vascular, fistula arterio-venoasă

${ }_{1}^{1}$ Lecturer PhD, Department of General Surgery, University of Medicine and Pharmacy “Victor Babes” Timisoara, Romania 2Surgery resident physician, $2^{\text {nd }}$ Surgery Clinic, Timisoara Emergency County Hospital no 1, Timisoara, Romania, corresponding author, $e$ mail address: iusti19@yahoo.com

${ }^{3}$ General surgery specialist PhD, Department of General Surgery, “Carol Davila” Nephrology Clinical Hospital, Bucharest, Romania

${ }^{4}$ Assoc. Professor PhD, West University of Timișoara, Faculty of Physical Education and Sports. Romania

5Assoc. Professor PhD, Department of General Surgery, “Carol Davila” Nephrology Clinical Hospital University of Medicine and Pharmacy "Carol Davila" Bucharest, Romania 


\section{Introduction}

End stage renal disease (ESRD) is a chronic medical condition that is mostly representative for elderly patients or those with low income and associated comorbidities (mainly diabetes mellitus), and has become a public health problem. The number of patients with ESRD is continuously increasing and although the number of renal transplant procedures has increased over the years, hemodialysis remains the only accessible therapy method for most patients. Hemodialysis requires a vascular access. According to the NKF-K/DOQI 2001 an arterio-venous fistula is the recommended procedure for obtaining the vascular access. An elbow fistula requires a vascular anastomosis between the brachial artery and the basilic, or the cephalic vein. Although it is not the first vascular access procedure recommended [1] it is the most frequent fistula performed. Establishing and maintaining the vascular access becomes the lifeline for ESRD patients and is one of the biggest problems in hemodialysis, with almost $20 \%$ of hospital admissions for these patients being for vascular access complications[2]. The quality of life (QoL) is usually poorer for patients with ESRD than in the age-matched general population due to the typically high rate of comorbidities and complications [3]. Therefore obtaining a good QoL in these patients is difficult and added to that is the impact that the vascular access has for the patients, because once the fistula is created the patients have to continuously monitor, care and protect it. Amongst the most important methods of self evaluation that the patients have to perform daily are: checking for signs of infection, checking to see if the thrill is still palpable, checking for swelling, keeping the area clean. The patients are also forbidden to lift heavy objects, traumatize the upper extremity, wear restrictive clothing and they have to avoid blood pressure cuffs or venipunctures. And finally added to all that the patient should also protect his contralateral upper extremity in case a vascular access needs to be created in the future. Considering all of the above our goal was to evaluate the impact that the vascular access (elbow fistulas) has on the patients QoL and analyze all the involved parameters.

\section{Material and method}

Our study was performed on consecutive patients with ESRD that had a first vascular access procedure performed (elbow fistula) in one of the two centers during July 2011-July 2013. Patients with a wrist fistula or any other form of vascular access for hemodialysis were excluded. All the patients completed the questionnaires preoperative and at 6 and 12 months follow up. Demographic, socio-economic and clinical characteristics were gathered and grouped into 6 categories as follows: Age, sex, educational level, socio-economic status, diabetes, cardiac disease. Education level was divided into three categories: low level (secondary school graduate or less), medium level (high school undergraduate or graduate), high level (college graduate). The socio-economic status was assessed as low $(<400$ euros/month income) or high $(>400$ euros/month income). QoL was assessed through the SF-36 form. The patients completed the forms before surgery and at, six months and one year after surgery. The SF-36 form is designed to assess overall functional status and well-being for adult patients compared with age-matched population norms. The form has 36 questions that assess 8 specific health domains [4]: general health perception, physical function, social function, role limitations attributed to physical problems, role limitations attributed to social problems, bodily pain, mental health and energy/fatigue. This instrument was selected because it is practical, well suited for clinical use, and inexpensive and has been validated in a variety of disease conditions in adults including ESRD. The score ranges from 0 to100 and the higher the score, the better the QoL.

For statistical data processing we used the following programs: Microsoft Excel 2010, Microsoft Access 2010, Epilnfo ${ }^{\mathrm{TM}}$ v.3.5.1, statistical calculations and graphics environment $\mathrm{R}$ version 2.15.0 with Rcmdr GUI version 1.8-3, Statistics v.10 (trial version) and IBM SPSS v2.1 (trial version).

\section{Results}

A total of 219 patients completed the SF-36 form prior to surgery, and at 6 months and 1 year after surgery. Demographic, socio-economic and clinical characteristics are shown in table I, with no significant differences between the two centers patients.

As shown in table 1 there is a predominance of patients over 60 years of age $(54.34 \%)$, also patients with a low socio-economic status $(87.20 \%)$ or a low educational level (56.62\%) represent majorities in their groups.

Table II shows the mean SF-36 scores for all the patients preoperative and postoperative. The results are grouped into the 8 SF-36 primary categories, as well as the two subtotals for physical and mental components. A graphic illustration of the differences between the SF-36 scores is shown in figure 1. 
Timişoara Physical Education and Rehabilitation Journal

Table I. Demographic, socio-economic and clinical data

\begin{tabular}{ll|c|c}
\hline Clinical characteristic & $\begin{array}{c}\text { Number of } \\
\text { patients }\end{array}$ & $\begin{array}{c}\text { Percentage } \\
\%\end{array}$ \\
\hline Age & Mean age & $60.62(21-83)$ & \\
& $20-40$ & 11 & 5.03 \\
& $41-60$ years & 89 & 40.63 \\
& $>61$ years & 119 & 54.34 \\
\hline Sex & Male & 137 & 62.55 \\
& Female & 82 & 37.45 \\
\hline Education level & Low & 124 & 56.62 \\
& Medium & 80 & 36.53 \\
& High & 15 & 6.85 \\
\hline Socio-economic & Low & 191 & 87.21 \\
status & High & 28 & 12.79 \\
\hline Diabetes & & 70 & 31.96 \\
\hline Cardiac disease & & 77 & 35.16 \\
\hline
\end{tabular}

Table II. QoL results

\begin{tabular}{lccc}
\hline SF-36 preopscores & Preoperative & $\begin{array}{c}\text { 6 months } \\
\text { follow up }\end{array}$ & $\begin{array}{c}\text { 12 months } \\
\text { follow up }\end{array}$ \\
\hline Physical functioning (PF) & 58.03 & 50.29 & 50.91 \\
Role-physical (RP) & 34.52 & 30.41 & 30.68 \\
Pain(P) & 49.69 & 41.05 & 41.18 \\
General health (GH) & 40.22 & 35.85 & 36.03 \\
Role-emotional (RE) & 56.80 & 53.88 & 54.84 \\
Social Function (SF) & 65.21 & 59.40 & 59.77 \\
Vitality (V) & 54.11 & 50.13 & 50.59 \\
Emotional well-being (EB) & 64.06 & 60.27 & 60.77 \\
Physical component summary (PCS) & 45.62 & 39.40 & 39.70 \\
Mental component summary (MCS) & 60.05 & 55.92 & 56.49 \\
\hline
\end{tabular}

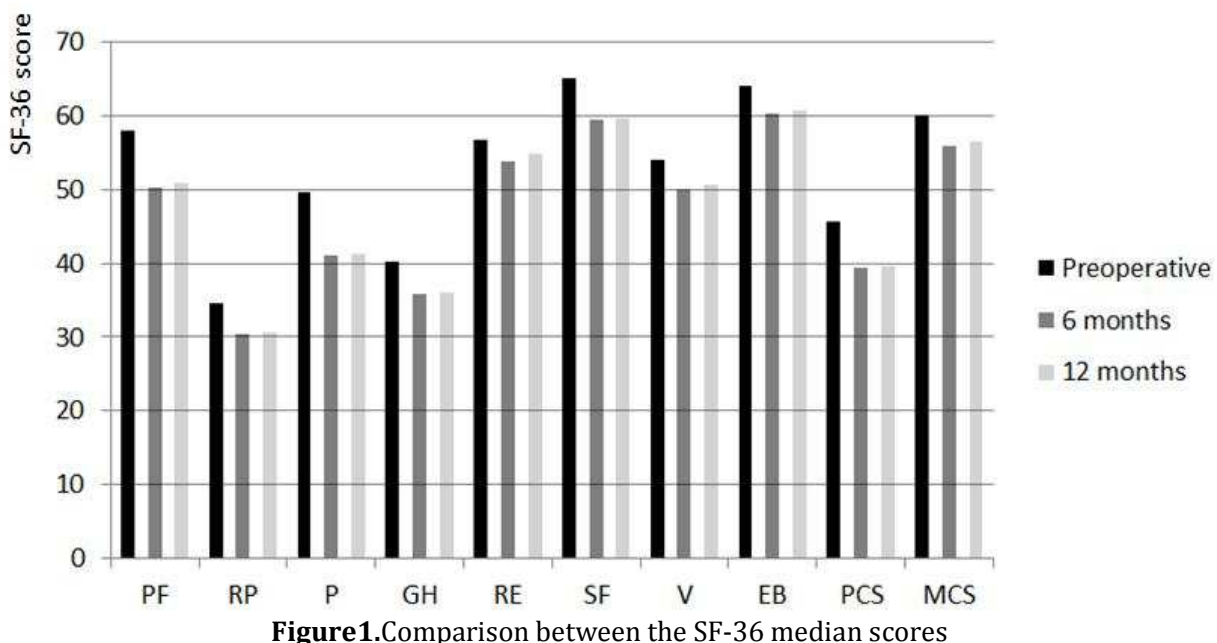

Legend: for SF-36 scoresPF: Physical functioning; RP: Role-physical, P: pain; GH: General health, RE: Role-emotional, SF: Social Function,V: Vitality, EB: Emotional well-being, PCS: Physical component summary, MCS: Mental component summary

\section{Discussion}

The SF-36 scores goal was to evaluate the impact that ESRD has on the patients QoL before surgery and the added impact that the vascular access has on the patients QoL. The SF-36 form is a specific recommended form for evaluating the QoL of patients on hemodialysis $[5,6]$.

SF-36 scores for all patients revealed a higher QoL before surgery. After the fistula was performed all patients had a lower QoL but with approximately the same value at the 6 months post surgery follow

Volume 7 Issue 14 \$2015 
up and 1 year after surgery follow up as shown in table II. The mean PCS score decreased with $13.63 \%$ after surgery for the 6 months follow up and 12.97 for the 1 year follow up. The mean MCS value also showed a decrease in the patients QoL with $6.87 \%$ at 6 months and $5.92 \%$ after 1 year. This proofs that the elbow fistula has a greater impact on the patients QoL physical component rather than on the mental component. Also because there were no significant differences between the patients QoL at the 6 months follow up and 1 year follow up we deduced from these values that once the patients got used to the impairments that the vascular access ads, they experienced the same QoL throughout the year.

Women scores revealed a lower QoL, especially in the 40-60 age group (16.62\% decrease for the PCS and $7.92 \%$ decrease for the MCS values), as seen in other literature data.[7,8,9] We also conclude that this can be attributed to the women's multiple domestic tasks and responsibilities compared to the men's.

Vascular access was better tolerated amongst younger patients, regardless of the sex, than elderly patients ( $>60$ years old). The mean decrease in the younger patients group was $10.20 \%$ for the PCS and $4.12 \%$ for the MCS compared to $19.11 \%$ for the PCS and $8.17 \%$ for the MCS values in the elderly patients group. The impairment that the elbow fistula has on the patients daily activities (clothing, eating, bathing) is significantly higher for elderly patients, making their day to day life struggles that more difficult, and ultimately affecting their QoL. Similar studies also support this statement. $[10,11]$

Similar to other studies [12,13] we also concluded that lower socio economic status is equal to a lower QoL after the creation of the vascular access (a decrease in the QoL of $15.11 \%$ for the PCS mean value and $8.12 \%$ for the MCS mean value). Most of our patients are from the group with the low socioeconomic status, and this is also revealed in their QoL assessment. These are patients that mainly depend on their family to aid them in their daily struggle, and once the fistula is performed, they depend even more on their family to help with the daily tasks.

\section{Conclusion}

Once the vascular access is created, patients must maintain their new lifeline through thorough self care actions and also by restricting their activities. Added to that the vascular access also becomes a stigma for the patients (scars, raised area on the forearm and arm)[8]. Maintaining an adequate QoL is therefore extremely important, because these patients rely on hemodialysis for the rest of their life, in absence of a renal transplant, and the vascular access is their only lifeline.

"Adding life to days and not just days to life" should be the main objective for these patients.Thus we believe that they could benefit from rehabilitation programmes in order to increase their QoL.

We also conclude that future studies may help to further clarify the association between vascular access and the patient's QoL in order to achieve this noble objective.

\section{References}

1. Tordoir J., Canaud B., Haage P., Konner K., Basci A., Fouque D et al. (2007) EBPG on vascular access. Nephrology Dialysis Transplantation, 22: ii88-ii117;

2. Saran R., Pisoni R.L., Weitzel W.F. (2004) Epidemiology ofvascular access for hemodialysis and related practice patterns. Contributions to Nephrology, 142:14-28;

3. DeOreo B.P. (1997) Hemodialysis patient-assessed functionalhealth status predicts continued survival, hospitalization and dialysis-attendance compliance. Am J Kidney Disease,30:204-212;

4. Ware J.E., Sherbourne C.D. (1992) TheMOS 36-item shortform health survey (SF-36).Med Care; 30:473-483;

5. Cagney K.A., Wu A.W, Fink N.E. et al (2000) Formalliterature review of quality of life instruments used in end stage renal disease.Am J Kidney Dis, 36:327-336;

6. Rettig R.A., Sadler J.H.,Meyer K.B. et al. (1997) Assessinghealth and quality of life outcomes in dialysis:a report on an Institute of Medicine workshop. Am J Kidney Dis, 30:140-155;

7. Martin-McDonald K., Biernoff D. (2002) Initiation into adialysis dependent life:An examination of rites of passage. Nephrology Nursing Journal, 29: 347-352;

8. Harris L.E., Luft F.C., Rudy D.W. et al. (1993) Clinicalcorrelates of functional status in patients with chronic renal insufficiency. Am J Kidney Dis, 21:161-166;

9. Rebollo P., Ortega F., Baltar J.M. et al. (1998) Healthrelatedquality of life (HRQOL) in end stage renal disease (ESRD) patients over 65 years.GeriatrNephrolUrol, 8:85-94;

10. Wasse H., Kutner N., Zhang R.and Huang Y.(2007) Association of initial hemodialysis vascular access with patient reported health status and quality of life.Clin J AmSocNephrol, 2(4):708-714;

11. Richard C.J., Engebretson J. (2010) Negotiating life with anarterio-venous fistula for hemodialysis . Nephrology NursingJournal, 37(4):363-375;

12. Blake C., Plant W.D. (2003) Measures to improve quality oflife in end stage renal disease patients. In:Brady H.D. andWilcox C.S. (eds).Therapy in Nephrology and Hypertension, Saunders, Philadelphia, 747-751;

13. Seica A., Segall L., Verzan C., Vaduva N., Madincea M., Rusoiu S. et al. (2009) Factors affecting the quality of life ofhemodialysis patients from Romania: a multicenter study.Nephrol Dial Transplant, 24:626-629. 